\title{
ACTUALITY AND “UNTIMELINESS" IN THE DISCOURSE ON THE REFUGEE CRISIS THE CASE OF HUNGARY ${ }^{1}$
}

\author{
ZSUZSANNA LURCZA*
}

\begin{abstract}
The figure of the refugee and asylum seeker, hidden from the masses, de-humanised, deprived of existence and rights, are in sharp contrast with their representation in the Hungarian mass media and in visual and textual materials of the Hungarian Governmental Information, which constructs a manipulated, extremist and xenophobic, ideologically biased reality. In this sense, the discourse on the refugee crisis has an "actual" and an "untimely" form. The first chapter of the paper is an ideology-criticism analysis, aiming at the deconstruction of the ideological subject-construct of the contemporary refugee existence. This analysis focuses on the Hungarian political language used to refer to the European refugee crisis since 2015, primarily the political questionnaire entitled "National Consultation on Immigration and Terrorism" and the text and poster campaign of the "Governmental Information" related to it, with references to the later, 2017 "Let's Stop Brussels" campaign, 2016 Hungarian "Migrant quota referendum", 2017 "Soros-plan" Consultation, and materials of the information campaign "Wirtschaft Zusammen Integrationsinitiativen der Deutschen Wirtschaft" in Germany. In the second part, this contemporary constructed form of refugee and asylum seeker existence is paralleled with its untimely discourse.
\end{abstract}

Keywords: refugee crisis, Hungarian political language, ideology-criticism, the untimeliness figure of the refugee, new (in)human condition.

\section{Introduction}

By the end of 2015, according to the data of UNO-Flüchtlingshilfe, there were as many as $65.6^{2}$ million refugees around the World - and even more - a number never seen since the Second World War, who became "useless" for world

\footnotetext{
${ }^{1}$ This work was supported by DAAD.

* Visiting researcher at the University of Kassel, 34125 Kassel, Kurt-Wolters-Str. 5. Email: lurcza_zsuzsa@yahoo.com

2 UNHCR The UN Refugee Agency: http://www.unhcr.org/en-us/figures-at-a-glance.html (Downloaded 13.01.2018)
} 
politics. Out of this number $17.2^{3}$ millions live the jungles of refugee camps and accommodation centres - as a sort of a post-colonial continuity - as technical management of political consequences, ${ }^{4}$ outlining the increasingly present refugee existence as a new stratum and category of the society. All these developments outline and actualize the idea, that the refugee - as Giorgo Agamben claims - is the only figure, which makes "the forms and limits of a coming political community" 5 visible; it is therefore necessary "to build our political philosophy anew starting from the one and only figure of the refugee". ${ }^{6}$ According to Agamben, the basic categories of the political systems in Western societies are no longer the "friend" and the "enemy," but rather the "bare life" and the "political existence". The contemporary European refugee crisis radicalizes this issue, ${ }^{7}$ and at the same time encourages us to analyze the deprived, excluded and impossible life form of the refugees in all aspects of human life, and at the same time to critically examine their ideological techno-political discursive subject-constructs, analysing their various power discourses, revealing their linguistic abuses, and thus give voice to the covert and suppressed discourses. Giving back, by this, the socially active, protesting, critical, "engaging" function of philosophy, or at least a kind of philosophy, for the present, for actuality.

\section{Deconstructing the Extreme Discursive Subject of the Refugee}

"Language is not a neutral medium for
communication but rather a set of socially
embedded practices. The reverse [...] is also
true: social interactions live linguistically
charges lives. That is, every social interaction
is mediated by language - whether spoken
or written, verbal or nonverbal."

(L. Ahearn $)^{8}$

${ }^{3}$ In addition there are 5.3 million Palestinian refugees registered by UNRWA, 10 million stateless people, and 189300 refugees resettled. Ibid.

${ }^{4}$ As Michel Agier claims in the Documentary film "Neue Heimat Flüchtlingslager" 2015.

${ }^{5}$ Giorgio Agamben: Homo sacer. Sovereign Power and Bare Life. Stanford University Press, Stanford, 1998. 16.

${ }^{6}$ Ibid.

${ }^{7}$ for its diversified perspectives including "questions the nomadic, migrating and commuting in light of wearable technologies and their infrastructures" see Tincuta Heinzel and Lasse Scherfig: Nomadic, Migrating, Commuting, Wearable Technologies and Their Infrastructures. In: Studia UBB Philosophia Vol. 62 (2017), 3. 6.

${ }^{8}$ Ahearn, M. Laura: Living language. An introduction to linguistic anthropology. Chichester, West Sussex: Wiley-Blackwell, 2012. 3. 
"The smartest way to keep people passive and obedient is to strictly limit the spectrum of acceptable opinion, but allow very lively debate within that spectrum."

$\left(\right.$ Noam Chomsky) ${ }^{9}$

The leading political programme of the Hungarian government on the refugee/migration crisis (fight for definition) ${ }^{10}$ is the 2015 "National Consultation on Immigration and Terrorism". The title of the Consultation ${ }^{11}$ already betrays the ideological nature of the political rhetoric by the term "national", which marks the government's ideological nation-building construction, in which the decisive place is given not to the citizen, the inhabitant, but to the "nation". This happens through a new kind of government communication based on (emotional) identity construction in the framework of a seemingly common task and purpose. The name "consultation" creates the impression that there is indeed a possibility for consultation, for the discussion and confrontation of opposing viewpoints, as well as for an active participation in the political life. However, the choice of the subject and the way of discussion is a propagandistic, manipulative, mobilizing and militaristic semantic strategy and communications form (of the direct marketing type), capable of creating moral panic. The first meaning of the noun "consultation", based on the Hungarian Interpretative Dictionary, ${ }^{12}$ is "request from an expert", which is not adequate in the case of a manipulative direct marketing strategy as a political questionnaire, addressed to the masses. The stigmatising noun "terrorism" is the keyword and leitmotif for intimidation and an all-encompassing existential panic, which intends to influence thinking, feelings, and actions. The term terrorism - a Latin loanword - actually means terror, horror, ${ }^{13}$ but its meaning derived from the French terreur means terrorism, the

\footnotetext{
${ }^{9}$ Noam Chomsky.

${ }^{10}$ "Interpretationsangebote sozialer Wirklichkeit mit impliziten Handlungsfolgen“ - Josef Kopperschmidt: Soll man um Worte streiten? Historische und Systematische Anmerkungen zur politischen Sprache. Liedtke 1991: 70-89. 83.

11 The fifth "political questionnaire" institutionalised by the second Orban government, which are direct marketing campaign letters sent to every Hungarian household.

12 Institute for Linguistics of the Hungarian Academy of Science (ed.): Hungarian Interpretative Dictionary. Academy Publishers, Budapest, 1959-1962.

${ }^{13}$ At this point we arrive at the problem of the definition of terrorism. The term is (ideologically) polysemous. Its undifferentiated interpretations and definitions embedded into various contexts seem to get blurred with the ambitions and self-legitimating language of power networks. The boundary between terrorism and war, terrorism and revolution, terrorism and common crime, terrorism and political violence, terrorism and fight against terrorism is blurred. The fight against terrorism often becomes a slogan arguing for the privatisation of war, or for profit-oriented "self-defence strategies" and humanitarian aid, "without pointing at the often very broad frontier territory between various forms of radical ideas and the irregular armed political conflict." In: Szilveszter Póczik: Az iszlám forradalom (The Islam Revolution). 13. IDResearch Ltd./Publikon Publisher, Pécs, 2011.
} 
rule of terror as well. At this point it seems to threateningly juxtapose and also organically connect the political discourse to the problem of immigration (Dysphemism), i.e. refugee crisis.

The refugee crisis appearing in Europe in 2015 is termed in the Governmental Information as "migration pressure". The focus of the discourse, especially in the introduction letter and in the questionnaire of the Consultation preceding the Governmental Information, is terrorism paralleled with "migration pressure", as a red herring-type distraction. The thematisation of terrorism is embedded within an intimidating, ethnocentric and exclusivist construction of social reality. The refugee crisis is completely excluded from the discourse, while the defence mechanism against immigration paralleled with terrorism is meant to justify the exclusionary legal modifications and the building of the "border barrier".

The introduction letter of the questionnaire outlines a deterrent actuality: "Europe was shaken by an unprecedented act of terror. In Paris the lives of innocent people were extinguished, in cold blood and with terrifying brutality". ${ }^{14}$ The first three and the sixth question of the questionnaire also refers exclusively to terrorism:

„1] We hear different views on increasing levels of terrorism [negative condition description]. How relevant do you think the spread of terrorism (the bloodshed in France [metaphor], the shocking acts of ISIS [metonym]) is to your own life? [Answers:] Very relevant, Relevant, Not relevant"15 - irrelevant parallel.

The EUROPOL report (EU Terrorism Situation and Trend Report - TE-SAT) says that terrorism includes the following categories: Islamists, separatists, leftist anarchists, rightists and single issue terrorists. The "Islamist" is a category that must be deconstructed, for it is presents one type of terrorism as overlapping with a world religion of more than one billion members. The question may be asked: why is there no Christian terrorism? Jacques Derrida also wonders whether the "letting die" attitude (J. Derrida, G. Borradori: Autoimmunity: Real and Symbolic Suicides - a dialogue with Jacques Derrida. By Jacques Derrida with Giovanna Borradori. In G. Borradori (ed.): Philosophy in a time of terror: dialogues with Jürgen Habermas and Jacques Derrida. University of Chicago Press, Chicago, 2003. 108.), the ignorance of several hundreds of millions who are starving, or are HIV positive, or live on territories afflicted by Ebola without proper cure, should not be considered terrorism, a deliberate terrorist strategy. The question is also valid with respect to the refugee crisis starting in 2015: the ignorance of the several million deaths in Iraq, Afghanistan, and Syria (who could be regarded as victims of the antiterrorist fight). Just as it is unclear what can be regarded as terrorism at a given time, it is also unclear what the fight against terrorism is. It is yet another question whether the series of illegal wars fought in the name of the anti-terrorist struggle cannot be regarded as a legal terrorism of some sort. There is a need for the deconstruction of the extremist rhetoric of "terrorism" and "international terrorism", its war-legitimating, intimidating and hatred-inciting status.

${ }^{14}$ For English version of the introduction letter and questionnaire published from Prime Minister's Office see: http://www.kormany.hu/en/prime-minister-s-office/news/national-consultation-on-immigration-to-begin 15 Ibid. 
"2] Do you think that Hungary could be the target of an act of terror in the next few years? [Answers:] There is a very real chance, It could occur, Out of the question.

3] There are some who [who are they? - argumentum ad verecundiam reference to unidentifiable authority] think that mismanagement of the immigration question by Brussels [metonym] may have something to do with increased terrorism. [In a deontic meaning: the migrants are \{potential\} terrorists.] Do you agree with this view? [Answers:] I fully agree, I tend to agree, I do not agree". ${ }^{16}$ - Complex question: a). "Brussels" handles "immigration" (refugee crisis) the wrong way. b.) The wrongly handled immigration (refugee crisis) is related to the spreading of terrorism.

"6] There are some who believe that Brussels' policy on immigration and terrorism has failed (metaphor), and that we therefore need a new approach to these questions. [flagword: suggesting a positive meaning; type of argument: institution $X$ has dealt with it this way - this is wrong, we do it differently / correctly.] Do you agree? [Answers:] I fully agree, I tend to agree, I do not agree" ${ }^{17}$ - Complex question: a.) Brussels' policy on the problem of immigration (refugee crisis) and terrorism has failed. b.) A new approach is needed.

The questionnaire conspicuously uses repetitions, makes ceaseless references to terrorism, generates a sense of endangerment and fear, suggests an identification of events, people or institutions with imminent danger, contains many expressions and metaphors with negative connotations or parallelisms with tragic events: "strengthening terrorist actions", "the spreading of terrorism", "the bloodshed in France", "the alarming actions of ISIS", "the target of terrorist actions is Hungary", "wrongly handled migration", and the verb "has failed".

The questions are strongly distorting, and define the subject and result of the Consultation from the very start. Supposedly a different kind of formulation of the questions could have resulted in a different conclusion of the Consultation (e.g., "How important do you consider to help people fleeing from war and terror?"). At the same time, the questions are just for appearance, they are selective, subjective and "informative", or more exactly manipulative, rather than exploring one's opinion. The language and logic of the questions is also worthy of attention: they are complex, and they formulate presuppositions and claims. They are also aggressive and dangerous, they leave no space for the respondent to actually express his or her opinion. Another problem with the questions is that

\footnotetext{
${ }^{16}$ Ibid.

17 lbid.
} 
giving a negative answer to them might be "risky", suggesting that the respondent is an "enemy" of their country or themselves, as they do not want to "live a secure life" and "wish harm" to their country.

The indefinite pronoun "different" (sokféle) in the first question merely makes reference to the existence of several "views", but does not list them, covering up thus the possibility of presenting other kinds of discourses. The "views" (vélemény) is used in the sense of "opinion", which is a subjective expression of somebody's thoughts or beliefs at a given time, a judgment, claim, suspicion or supposition based on probability. Through these means, the questions are presented as opinions, where one's own "opinion" can be understood in fact as a manipulative popularisation of one's own ideological discourse, and the construction of an extreme reality.

Terrorism appears in the first question in relation with one's own life, and in the second question as which targets Hungary. Both questions suggest the intimidating deontic meaning that one has to face an extreme situation in which one's life and country is / could be threatened by terrorism. The third complex question suggests the deontic meaning that "Brussels" is responsible for the spreading of terrorist attacks. The claim of an organic connection between "terrorism" and "immigration" in the third question also creates the impression that immigration (i.e. refugee crisis), similarly to terrorism, threatens the respondent's existence. This parallel also prepares the field for the supposition that the strategies to tackle "terrorism" and "immigration" (i.e. refugee crisis) must also be similar, meaning that immigrants (asylum seekers and refugees) must also be eliminated and fought against.

References to the events of Charlie Hebdo use and amplify the negative association constructed in the media that the entire life sphere of members of the western society has been jeopardised: its fundamental values, such as freedom of speech, democracy, culture, homeland, and ultimately their physical existence. Making this reference also creates the possibility of identification, since after the actuality-constructing media coverage of the event the whole world chanted "Je suis Charlie". The reference to ISIS brings this impression even closer. Another aspect to be mentioned is the use of the relative pronoun "who" ("there are some who") - there are no (authentic) sources listed for the information presented as objective -, suggesting that there are "those people" with an unknown "them" behind them.

The "European Union" is replaced in the questions by "Brussels", although the EU and Brussels are not an identical entity. Hungary is also a member of the $\mathrm{EU}$, therefore the respondent could identify with it in some respects. However, 
this cannot be said about a metonymical "Brussels", which creates here the impression of a distant, strange, "extra-national" power, and stigmatises the use of the EU concept. This is the general rhetoric of the April and May 2017 "Let's stop Brussels!" Consultation and billboard campaign.

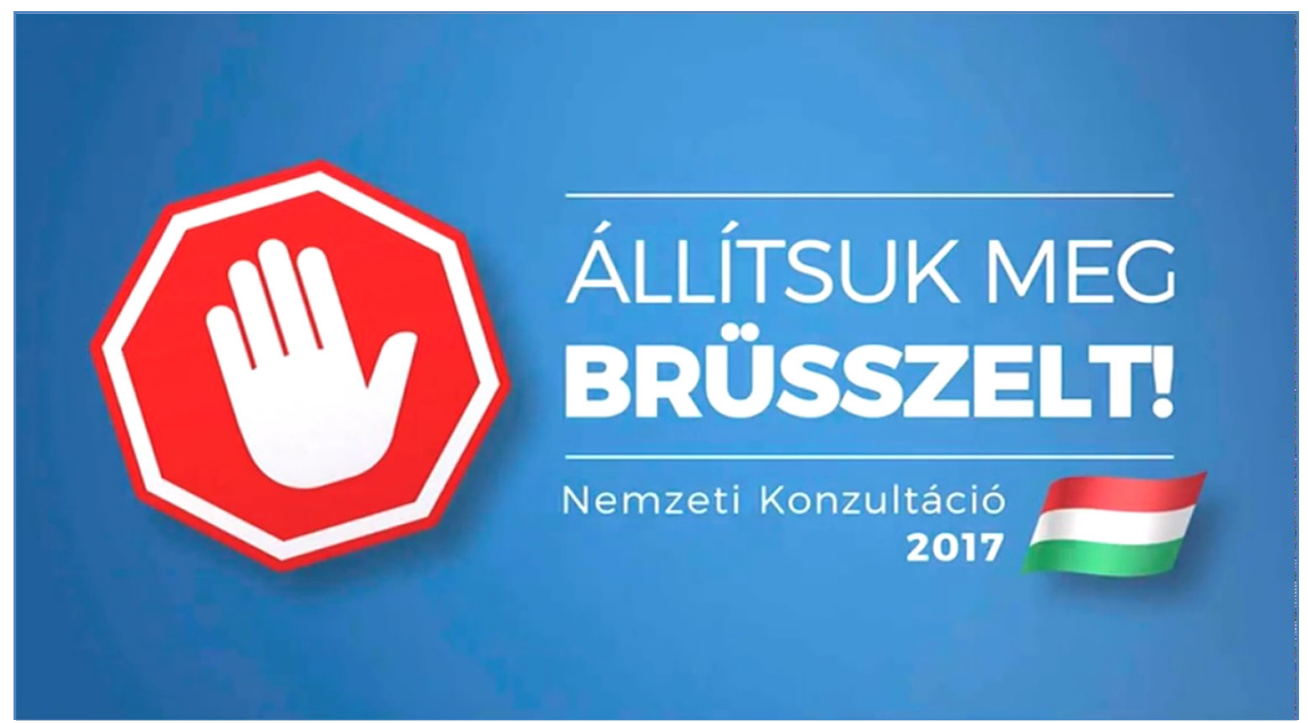

Figure 1. "Let's stop Brussels! National Consultation 2017".

The "Let's stop Brussels!" Consultation continues and increases the criminalisation of the refugees, asylum seekers, and their identification with terrorism, as well as the construction of the sense of endangerment. This Consultation contains six questions. These, in addition to openly attacking "Brussels" and non-governmental organizations, also deal with the problem of "illegal immigrants" in one question, and the criticism of the international organizations of migration aid in another one. The second question of this Consultation asks: "In recent times, terror attack after terror attack has taken place in Europe. Despite this fact, Brussels wants to force Hungary to allow illegal immigrants into the country. What do you think Hungary should do? (a) For the sake of the safety of Hungarians [flagword] these people should be placed under supervision (felügyelet) while the authorities decide their fate. (b) Allow the illegal immigrants to move freely in Hungary" ${ }^{18}$ The deontic meaning of the propagandistic question above can be reconstructed as follows: 1 . There are more

18 English version of the questionnaire of "Let's stop Brussels!" Consultation see: http://hungarianspectrum.org/2017/04/02/national-consultation-2017-lets-stop-brussels/ 
and more terrorist attacks in Europe. (2. The terrorist attacks are committed by immigrants, as it becomes more evident later from the billboard campaign of the Hungarian "Migrant quota referendum" in 2016).

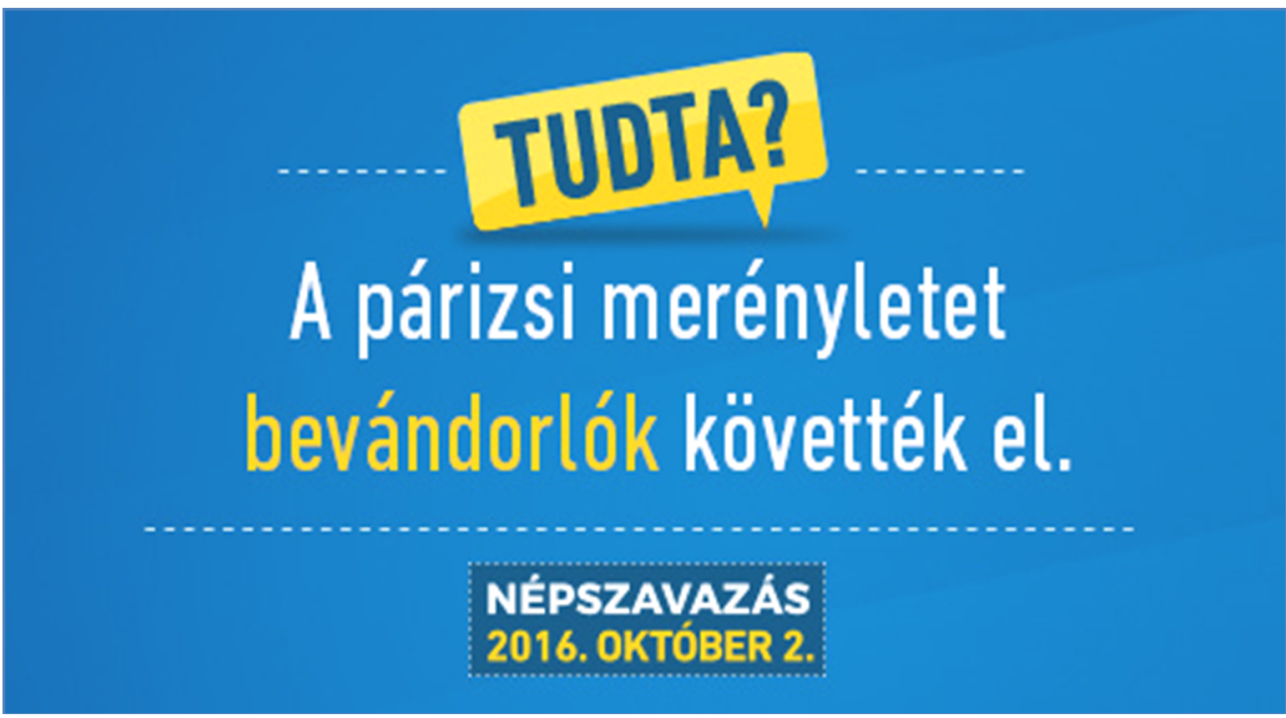

Figure 2. "Did you know? The Paris terrorist attacks were carried out by immigrants Referendum 2016. October 2."

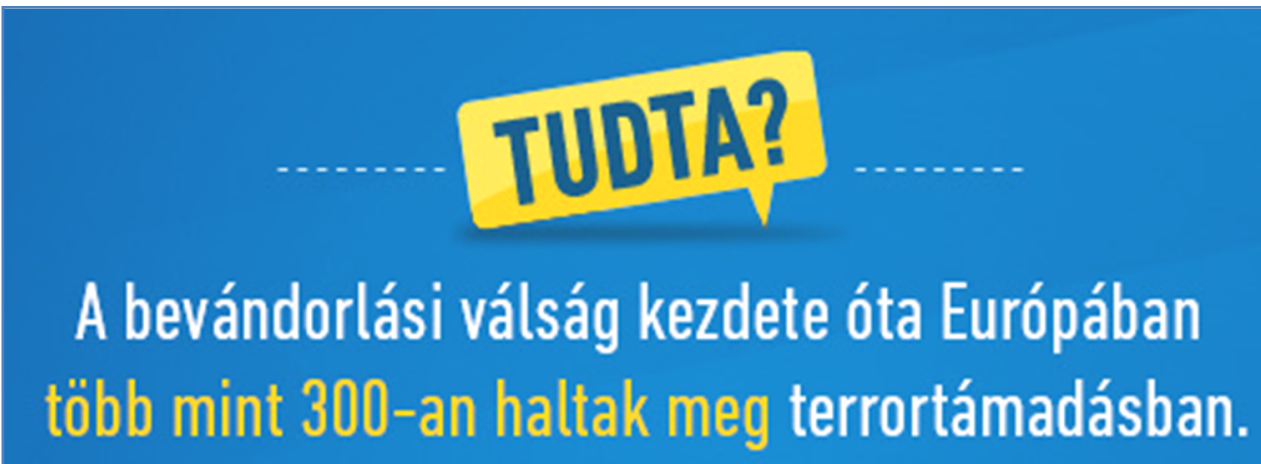

NÉPSZAVAZAS 2016. OKTÓBER 2.

Figure 3. "Did you know? More than 300 people were killed in terrorist attacks in Europe since the start of the migrant crisis" 
3. Brussels wants to force Hungary to let illegal immigrants in. ${ }^{19}$ (4. If we let illegal immigrants in, they could commit terrorist attacks in Hungary as well.) 5. Brussels wants to force Hungary to subject to the possibility of future terrorist attacks on its territory. In addition, "security" is a flagword which grounds the language of the consultations, which are fixed in social awareness as a result of, and associated with, governmental measures, in a positive sense, as the (single) safeguard of security.

A decisive phenomenon in the text of the introduction letter and questionnaire of the "National Consultation on Immigration and Terrorism" and the Governmental Information is the way the problem is formulated: the thematisation of terrorism and immigration versus the avoidance to thematise the refugee crisis, the quality of the terms used, the conscious mixture of terms with different meanings: the repeated, frequent use of "illegal border crosser", "migrant", "illegal immigrant", "immigrant who illegally crosses the border", "economic migration", versus the avoidance to use the terms refugee and asylum seeker. The text contains no such terms as "citizen", "stateless", "refugee" or "asylum seeker", terms that could imply that these people have some kind of rights or are entitled to claim rights; they are only described as having illegal qualities. This valuedeprived language use is meant to influence how the public opinion thinks and acts about it, and what status it attaches to the people described in these terms. The undifferentiated, multi-sense use of the term "immigrant" is at the same time ambiguous and misleading. Is it intentional never to clarify what this political term means in its various uses? This ideological polysemy makes it possible to merge various semantic fields: immigration and terrorism, immigration and refugee crisis, immigration and groups with a migrant background. The purposeful exchange of various terms favours the extreme reality-constructing discourses of the power structures, and this is what legitimates the deconstruction of concepts and attitudes. The various terms and names are attached to radically different political and legal procedures. The terms with negative connotation (e.g. terrorist) come to the forefront, enjoy large media coverage, and are present in the political discourse, while other terms (such as asylum seeker and refugee) get no publicity.

The subjects of the Consultation - as viewed by the technical-medialpolitical mechanism of the government - are not refugees, nor potential asylum

\footnotetext{
19 The logic of the "National Consultation on immigration and terrorism" from 2015 will be radicalised in the further "Migrant quote referendum" in 2016 and Consultations.

By the Referendum we can also find the governmental billboard campaign with the following phrase: „Did you know? Brussels wants the forced resettling of a city's worth of illegal immigrants into Hungary"
} 
seekers, and do not need any humanitarian aid, they only started out in the hope of a better life. The discourse on refugee crisis gets thus distorted, focusing, instead of humanitarian aid, on a defence strategy, on the "migration pressure" and "modern-age migration period" that has put the country at risk, on crime and violation of the law, criminalizing and alienating the asylum seekers, and constructing the image of an enemy at the same time. All these discourses and extreme rightist argumentations produce a xenophobic and ethno-centric reality, which functions as a pseudo-actuality, a programmed actuality, an "ArteFakt", a "reality" that has its own constructors and censors.

\subsection{The introduction of the Governmental Information about the Consultation}

The Governmental Information publishes the result of the Consultation with the following slogan and performative, activating call: "People have decided: [synecdoche: not all people, only a part of the people, who are nonrepresentative for the entirety of citizens] $]^{20}$ the country must be defended", as also written on the "informative" billboard-campaign of the Consultation.

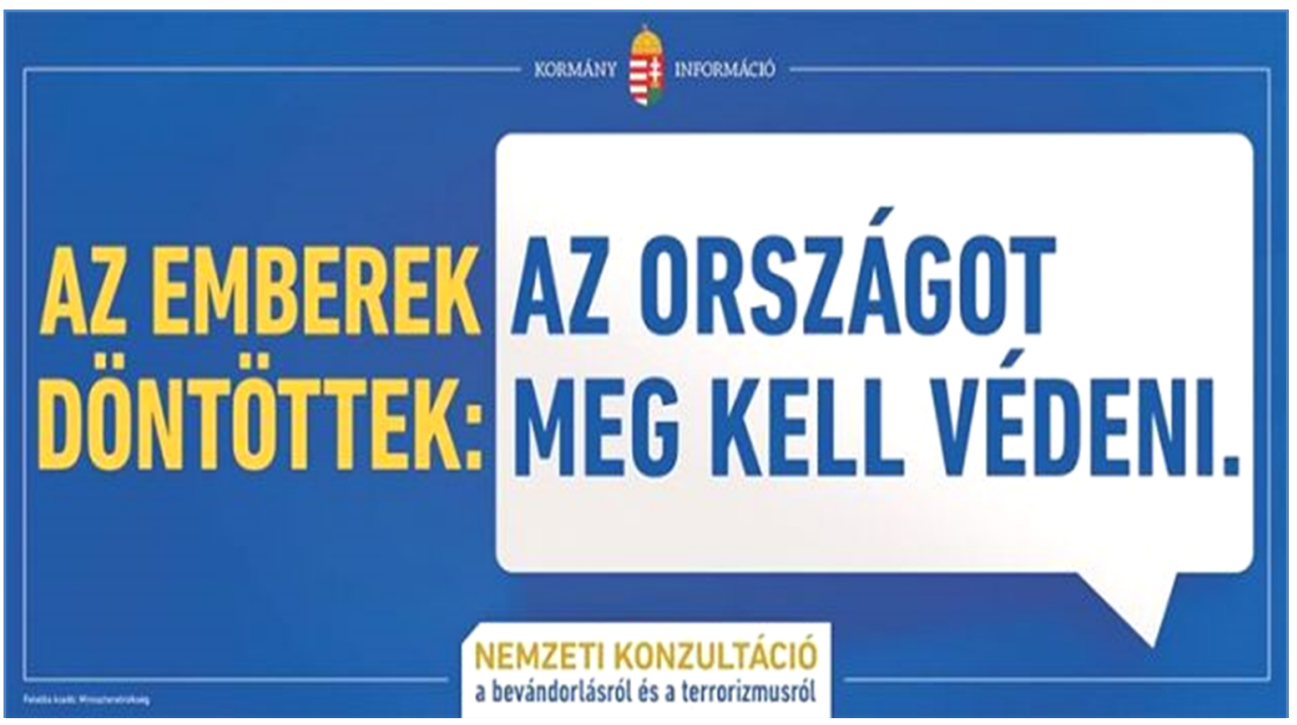

Figure 4. "Governmental Information. People have decided: the country must be defended. National Consultation on immigration and terrorism"

208 million posted questionnaires were filled in by 1 million 58 thousand people 
"The country must be defended" is a euphemistic call, because the "defence" strategy of the Consultation targets precisely the rejection of help, the introduction of exclusionist law amendments, and the building of a "border barrier".

After the slogan, the introduction of the Consultation informs the reader, formulating and at the same time constructing the reality: " $\underline{A}$ never before seen migration pressure [a metaphor referring to an external, alien force, enhanced by the term "migration", coming from a foreign language] is weighing down on Europe, and on our country as well. The past few months have witnessed a drastically [negative adverb] increasing number of people illegally entering ([Dysphemism], that is, asylum seekers) Hungary. By the middle of October more than 380 thousand people have crossed the border illegally. The EU is also responsible for this situation, because it has encouraged the migrants to leave their country and head for Europe. This is a question that greatly determines our daily life and our common future. If we fail to take action, we shall not recognize our own country in a few decades' time [false dilemma]. For these reasons, the government has started a consultation about migration and terrorism". ${ }^{21}$

The introductory part of the Governmental Information contains references to the extraordinary situation and illegality, as well as intimidating and pressuring phrases: "never before seen [...] pressure", "drastically", "illegal". The Consultation is legitimate because the present situation determines and even endangers the "common future", because, as a negative connotation, an activating and mobilising element, it gives the impression that "If we fail to take action, we shall not recognize our own country in a few decades' time". This, based on Austin's speech act theory, can be understood as a threatening illocution. The respondent has to face a false dilemma here, which heavily restricts the possible options, while it also works as an "all or nothing", a black-or-white argument: we either accomplish our programme, or "we shall not recognize our own country", meaning that the programme of the Consultation must be accepted! This is also a sort of political/poetical exaggeration, a hyperbole, and also shadowboxing.

Elements that suggest division are also notably present ("our" common future, "our" country) between "Us" and "Them", the "Hungarian people" and the "immigrants", or the "Hungarian people" and "Brussels", the "EU". Besides the concrete formulation, this aspect is also enforced by the use possessives, and the integrative, first person plural communication: "our country", "our daily life and our common future", "if we fail to take action", "we shall not recognize our own country", "our own life", "we cannot allow", "we have the right to protect our

21 The full text of the Governmental Information was accessible through the link: http://nemzetikonzultacio.kormany.hu/ 
culture, language and values". The horror of negative elements is topped by references to steadiness, as the dangers listed threaten our "daily life".

\subsection{Results of the Consultation presented in the Governmental Information}

The introduction of the Governmental Information is followed by the results, published by the Prime Minister's Office: "The Hungarian people (highvalue word) consider that the issue of migration is important for their own lives. This is proved also by the fact that more than 1 million people filled in and sent back the questionnaire. The results show that the people's opinion is clear: Hungary must be defended [metaphor - militarised language use]. More than 90\% of the respondents agree that the EU's migration policy [(dysphemism), i.e. refugee policy] has failed, therefore stricter regulations are needed. The vast majority of the people think that the first step to take is to send back the migrants as soon as possible [(euphemism), i.e., expel them] who crossed the border illegally [(dysphemism), i.e., asylum seekers]. Hungary and Europe cannot accept everyone". ${ }^{22}$ - Euphemism: Hungary will not accept anyone. Here, instead of "Brussels" (EU), the term "Europe" is used, because the EU (despite the varying attitude of the member states) does not outright reject the acceptance of refugees. The term "Europe" wishes to neutralise this aspect.

The paragraph about the results starts with the "Hungarian people" and "their own lives". The term "Hungarian people" that has a central role in the government's ideological dictionary is contrasted with the illegal foreigner. The "Hungarian people" is a repetitive high-value word, which reminds the respondents that they are "Hungarian", and exclusively Hungarian (and not of any other nationality or members of other ethnic groups living in Hungary, whether or not they have Hungarian citizenship, residence permit, or permanent residency or inhabitancy in Hungary). People living on the territory of the country are thus important for the government merely because of their being Hungarian, as national subjects. The repetition and emphasis of the term "Hungarian people" also marks the marginalization of various social groups and structures.

The results of the Consultation repeat the formulations of the questionnaire, this time as the people's opinions. This shows that the previous "(statement-like) questions" of the government now appear as a legitimate political-legal practice. The speech act and normative statement emphasised in bold, "Hungary must be defended", has a mobilising, but at the same time also intimidating effect. The phrase "has failed" is also repeated several times, introducing and legitimising the "stricter regulations".

\footnotetext{
22 Ibid.
} 
The Governmental Information - as a demonstration that the majority is supporting it - also emphasises on the basis of the responses that the "opinion" of the people is "clear". The following expressions and phrases suggest that the government's decision is taken based on a unanimous agreement: "proved", "the people's opinion is clear", "more than $90 \%$ of the respondents," "the vast majority of the people". However, this demonstration is questionable, as the ideologically biased political questionnaire of the Consultation is manipulative, and it does not apply the professional principles of a poll, there are often two answers about acceptance and one about rejection, and the evaluation criteria are also unknown. The authenticity of later consultation is further questioned by the fact that the November-December questionnaire of the "Soros-plan" Consultation can also be answered online, but the online questionnaire lacks the basic security and authenticity controls. ${ }^{23}$

\subsection{Government measures presented in the Governmental Information}

The government has taken the following measures to tackle the problems raised by the National Consultation: 1. "The government's position is clear: the frontiers of Europe and Hungary must be defended by all means! [metaphor]. The cabinet has decided therefore to build a temporary technical border barrier [(euphemism), actually a $4 \mathrm{~m}$ high, $175 \mathrm{~km}$ long razor wire fence] on the HungarianSerbian and Hungarian-Croatian border. In order to handle [(euphemism), i.e. the rejection to "handle" it] the migration situation, the government enforced the police, and made military intervention possible at the southern border". ${ }^{24}$

The warning of the introduction "must be defended!" is repeated and increased in a new context, where the phrase "by all means" is left purposely ambiguous and may entitle for anything, may confirm the legitimacy of any indefinite, unknown future plan. The term "clear" is also repeated, now in relation to the government, "harmonising" the position of the people and the government. The government's measures come as a comforting element relieving the tension: "building the border barrier", "handling the migration situation", "enforcing the police", "make military intervention possible". The impression created by the first point of the measures is full military preparedness, which offers protection against illegality and terrorism, and ultimately, implicitly, against the enemy.

\footnotetext{
${ }^{23}$ The questionnaire can be accessed on the webpage https://nemzetikonzultacio.kormany.hu/, it requires 3 short stages to fill in: 1. "authentication" with the following data: first name, last name, e-mail address, age. However, the truthfulness of the data is not controlled; anything can be written in the system. Any number of answers can be sent in from one single IP address.

${ }^{24}$ Ibid. http://nemzetikonzultacio.kormany.hu/
} 
Military preparedness is also meant to justify the generated atmosphere that the respondent is in a life-threatening situation in many respects: their own physical existence (existential context), the security of their country (security policy context), its fundamental values and culture (cultural context), fundamental rights (legal context), and subsistence (economic context) - and this threat is what must be fought against. The identification of the asylum seekers with potential threat in the mass media also appears in a different context, in which asylum seekers are represented as carriers of viruses and infectious diseases (health context). In addition, the semantics of government measures suggests the positive connotations of security, protection and conservation, compared to which the EU becomes a symbol of irresponsible and failed politics.

The military-warfare rhetoric calls for a multi-front fight in the text: on the one hand, for protection against immigrants (asylum seekers) and terrorists, and on the other hand, for a kind of war of freedom against "Brussels". The doublefront fight as an allegory covertly also constructs another dimension of meaning. It covertly calls on the freedom struggles in $19^{\text {th }}$ and $20^{\text {th }}$ century Hungarian history, the 1848 and the 1956 revolutions, the latter triggered by the Soviet invasion. There is an implicit suggestion for drawing a parallel between the Soviet occupation and the limitations of sovereignty implied by the EU membership, although the two situations are radically different: the Soviet occupation was a military invasion following a lost war, but the EU membership was a voluntary choice of the country. The negative semantic connotations of the "EU", "Brussels" as the source of troubles, the EU as a political failure, and the fight against it are also referred to by the following formulations: "The EU is also responsible for this situation", "it has encouraged the migrants to leave their country and head for Europe", "the EU's migration policy has failed", and the countries of Central Europe "cannot afford to be affected by the flawed politics of Brussels"; from the introductory letter of the Consultation: "Brussels and the European Union are not capable of handling the question of migration in an adequate manner", "Brussels has failed in the handling of migration", 25 "Hungary must take its own path". The allegory of the war of freedom culminates in the Prime Minister's ideological 15 March 2017 speech. ${ }^{26}$

The defensive war rhetoric is apparent in the text through the following textual units: "A never before seen migration pressure is weighing down on Europe, and on our country as well" (allegory of invasion), "If we fail to take action, we shall not recognize our own country in a few decades' time", "Hungary

\footnotetext{
${ }^{25}$ https://theorangefiles.hu/2015/05/19/national-consultation-on-immigration-and-terrorism/

${ }^{26}$ https://www.youtube.com/watch?v=1YGZoG8XnuU
} 
must be defended", "the frontiers of Europe and Hungary must be defended by all means", the cabinet "has decided to build a temporary technical border barrier on the Hungarian-Serbian and Hungarian-Croatian border", and the government "enforced the police, and made military intervention possible at the southern border", "the modern-age migration can be stopped", "the southern security border barrier is functioning", "we cannot allow them [...] to jeopardise the jobs and security of Hungarian people", "we have the right to protect our culture, language and values", "we cannot allow". Reference to illegality: "the number of people illegally entering Hungary has drastically increased", "more than 380 thousand people have crossed the border illegally", "stricter regulations are needed", "send back the migrants as soon as possible who crossed the border illegally", "the tension is relieved by stricter laws." Based on all this, the text constructs the impression that the refugee crisis, its interpretation and solutions can only be conceived in the framework of military action and criminal law, and definitely not in a humanitarian perspective.

2. "The tension of the migration is relieved [(euphemism); actually, the rejection of the asylum seekers] by stricter laws. Based on recent laws, the illegal crossing of the border and the damaging of the border barrier is a criminal act, and human trafficking is punished more strictly. Criminal acts are evaluated out of turn, illegal immigrants [asylum seekers] will face prison or expulsion". ${ }^{27}$

Point 2 proves continuing and increasing government measures meant to "relieve the tension" through amendments to the Penal Code. This point outlines how linguistic structures and discourses relate to state political and legal acts, how they become the legal constructors of social reality. Following the amendments, "The Government is entitled to establish in a decree the list of origin countries declared secure by Hungary on a national level, and secure third countries." Based on this, since 2015, Serbia counts as a secure third country, the applications of asylum seekers coming from Serbia are never reviewed, and the applicants are rejected.

Since these amendments, the illegal crossing of the border barrier is a criminal act, for which the perpetrator can be punished with imprisonment for up to three years. "For cases of this criminal act the law orders imprisonment from one to five years, two to eight years, and in the aggravated cases from five to ten years". Damaging the border barrier and impeding the building of the fence are also crimes. The concept of "crisis situation caused by mass migration" is introduced, asylum seekers may hand in their applications before they enter the territory of Hungary, in the transit zone, during a procedure at the frontier.

\footnotetext{
${ }^{27}$ Ibid. http://nemzetikonzultacio.kormany.hu/
} 
Another amendment is that a soldier's use of "rubber bullets, pyrotechnic articles, tear gas grenades, interceptor nets shot to the target with firearms or other launching devices do not qualify as firearm use" in a crisis situation caused by mass migration. The term of "crisis situation caused by mass migration" is used as a new, legitimate overwriting of existing laws, and a justification of new, yet unknown strategies. Agamben's formulation is pertinent in this respect: „Heute ist die Krise zum Herrschaftsinstrument geworden. Sie dient dazu, politische und ökonomische Entscheidungen zu legitimieren, die faktisch die Bürger enteignen und ihnen jede Entscheidungsmöglichkeit nehmen. [...] Die europäischen Bürger müssen sich klarmachen, dass diese unendliche Krise - genau wie der Ausnahmezustand - mit der Demokratie inkompatibel ist". ${ }^{28}$

The legal interpretive framework that penetrates the Consultation moves the emphasis from the humanitarian catastrophe and moral responsibility to the illegality and criminality of the "migrants", under the effect of the criminal law, and ultimately within the framework of the "state of exception". The Amnesty International reports that by the end of 2015 "over 900 people were prosecuted for "illegal border crossing" and subjected to expulsion proceedings". ${ }^{29}$ Finally, as an embellishment, the details of the amendment also reveal that "who obtains asylum cannot be expelled". ${ }^{30}$ But how can one obtain asylum? The criminalisation of illegal border crossing and the closing of the borders as well as the amendments impose limitations and make it impossible to seek asylum.

3. "Hungary has proved [metonymy: "Hungary" instead of the "Government of Hungary", a new meaning is constructed: the respondents can more easily identify themselves with Hungary] that the modern-age migration can be stopped [negative metaphor]. The southern security border barrier [an excluding fence] is functioning, it successfully fulfils the role assigned to it by the government, it stops illegal border crossings". ${ }^{31}$

Point 3 is an argument for the correctness of the procedure. It only contains the success of the government's measures, expressed in positive expressions: "has proved", "is functioning", "successfully fulfils its role", "stops" illegality, therefore the problem is solved.

Point 4 repeats and summarises everything said before, and ends the Consultation: 4. "We cannot allow $[W e]$ the illegal immigrants [Them] to

\footnotetext{
${ }^{28}$ Giorgio Agamben in FAZ from 25.05.2013.

29 Amnesty International Report 2015/2016. The State of the World's Human Rights. 180. https://www.amnesty.org/en/documents/pol10/2552/2016/en/ (accessed: 20.07.2017).

${ }^{30} \mathrm{lbid}$. http://nemzetikonzultacio.kormany.hu/

31 Ibid.
} 
jeopardise the jobs and security of the Hungarian people. We have the right [argument of the legitimacy and correctness of their procedure] to defend ["Our" own] culture, language and values [as opposed to "Theirs"]. The countries of Central Europe, which have only recently recovered from the economic crisis [argumentum ad misericordiam], cannot afford to be affected by the flawed politics of Brussels". ${ }^{32}$ - The Central European countries, the Visegrad Four, receive a special status here: as suggested by mass media channels, these appear as a new unit opposed to the EU, as a possibility of an alternative political community within the EU which is legitimised precisely by the existing both theoretical and practical weak points in politics, e.g. in relation to the question of the union and national sovereignty.

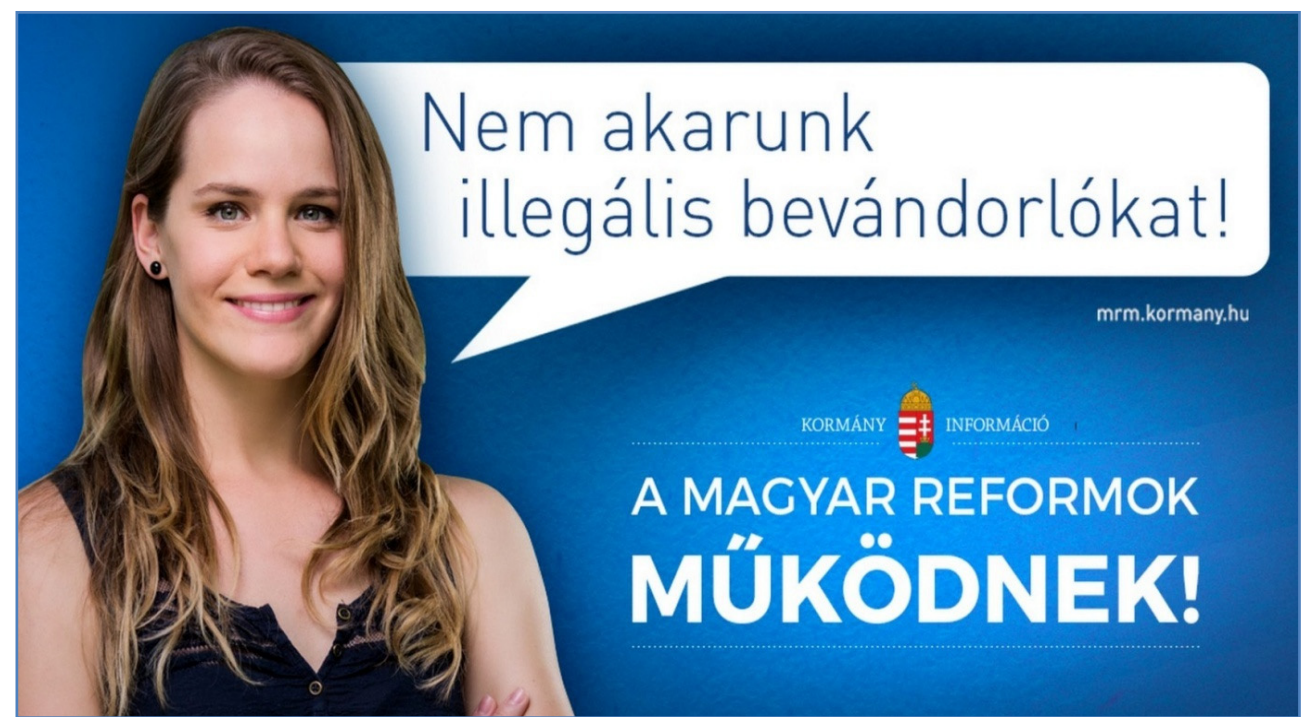

Figure 5. Government billboard from 2015: “We don't want illegal immigrants. Governmental Information. Hungarian reforms work!"

The speech act "we have the right to defend our culture, language and values" is repeated and it has a mobilising and legitimating character; the warnings "we cannot allow", "cannot afford" are also repeatedly used. All this draws the attention to an "extraordinary" situation where "Our" culture, language and values have been jeopardised as opposed to "Their" culture, language and values, suggesting a possible clash of civilisations. Consequently, we must defend

${ }^{32}$ Ibid. 
ourselves against the opponents, the source of danger, actually the enemy. The phrases "we cannot allow", "we have the right" are also performative statements mobilising for the constructed truth and for the fight against the constructed injustice. Point 4 presents the government's position as sacred, and the appeal to fear and feelings is also a general aspect.

The sense of being threatened is increased and a new element is introduced: the "illegal immigrants" who jeopardise the people's security also endanger their jobs and consequently subsistence, causing social insecurity. In addition, the flagword "security" can be easily activated in this case also because of the rising need for security, and gains its force precisely from insecurity and the fear about insecurity. Points 4 and 5 of the questionnaire present the asylum seekers as "economic migrants" ["megélhetési bevándorlók": subsistence migrants], who jeopardise the "Hungarian people's" jobs and subsistence, where the attribute "economic" ["megélhetési": subsistence], implicitly refers to their "uselessness" and profit-seeking intention. This is described in details in the introduction letter of the questionnaire: "Economic migrants ["megélhetési bevándorlók": subsistence immigrants] cross our borders illegally [deontic meaning: they are criminals], and while they present themselves as asylumseekers, [deontic meaning: they are cheaters], in fact they are coming to enjoy our welfare systems and the employment opportunities our countries have to offer [to profit from us]. In the last few months alone, in Hungary the number of economic migrants ["megélhetési bevándorlók": subsistence immigrants] has increased approximately twentyfold [now the cheater criminals are profiting from us twentyfold]. This represents a new type of threat - a threat which we must stop in its tracks". ${ }^{33}$ - Intimidation, enemy-building, mobilization, militarization through aggressive speech act. This "new" type of threat means also that we are not prepared for managing it, and we are vulnerable. But we must decide now about managing the threat, and the consultation is offering a way to do this: "We must make a decision on how Hungary should defend itself against illegal immigrants". ${ }^{34}$ This way is that one which is identical with the government's visions, and the two groups are "They", the illegal economic immigrants and "We", the Hungarian People: "We shall not allow [integrative, mobilizing speech act] economic migrants to jeopardise the jobs and livelihood of Hungarians". ${ }^{35}$

The questionnaire also mirrors this opposition presented as a conflict of interests, or even as a struggle for subsistence: "12] Do you agree with the

\footnotetext{
${ }^{33} \mathrm{lbid}$. http://www.kormany.hu/en/prime-minister-s-office/news/national-consultation-on-immigrationto-begin

${ }^{34} \mathrm{Ibid}$.

35 Ibid.
} 
Hungarian government that support should be focused more on Hungarian families and the children they can have, rather than on immigration? [Answers:] I fully agree, I tend to agree, I do not agree". ${ }^{36}$ - Here the integrative "we" for Hungarian families and Hungarian children and "they" for the immigrants (and the immigrants' children) is also used.

In the introduction letter presented, apparently factual and unambiguous statements will be questioned in the questionnaire.

„4] Did you know that economic migrants ["megélhetési bevándorlók": subsistence migrants] cross the Hungarian border illegally, and that recently the number of immigrants in Hungary has increased twentyfold? [Answers:] Yes, I have heard about it, I did not know.

5] We hear different views [which ones?] on the issue of immigration. There are some who [who are they?] think that economic migrants ["megélhetési bevándorlók": subsistence migrants] jeopardise the jobs and livelihoods of Hungarians. Do you agree? [Answers:] I fully agree, I tend to agree, I do not agree". $^{37}$

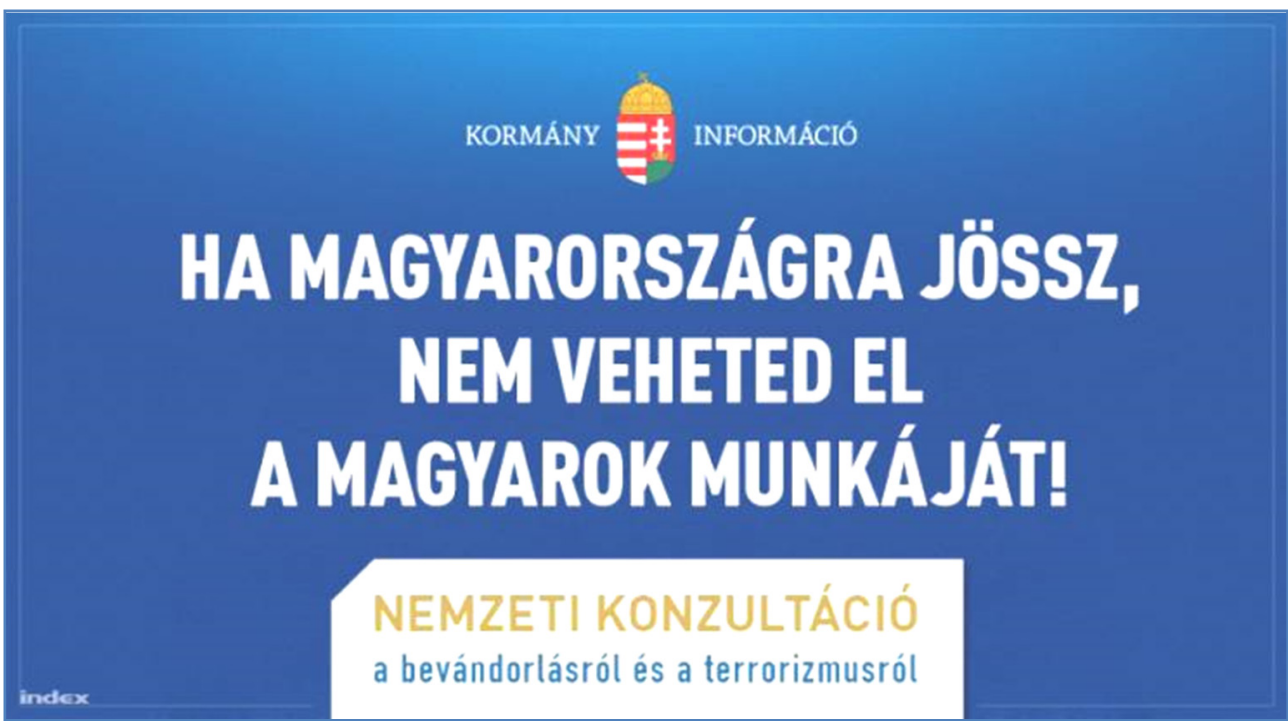

Figure 6. "Governmental Information. If you come to Hungary, you cannot take away the jobs of the Hungarians! National Consultation on immigration and terrorism".

\footnotetext{
${ }^{36}$ Ibid.

${ }^{37}$ lbid.
} 
In this context the billboard of the "National Consultation on Immigration and Terrorism" warns that "If you come to Hungary, you cannot take away the jobs of the Hungarians!" Since the language of the billboard campaign is Hungarian, the addressees of this campaign are primarily the "Hungarian people" rather than anyone else.

However, this prohibition gives way to a different rhetoric, namely that the refugees and those who come to Hungary live on the taxpayers' money. The alternative is offered in point 10 of the questionnaire: "10] Do you agree with the concept that economic migrants ["megélhetési bevándorlók": subsistence migrants] themselves should cover the costs [i.e. \{forced\} community service] associated with their time in Hungary? [Answers:] I fully agree, I tend to agree, I do not agree". ${ }^{38}$ The procedures applied by the government, as seen in points seven, eight and nine of the questionnaire, offer an alternative to these dangers:

"7] Would you support the Hungarian Government in the introduction of more stringent immigration regulations [an exclusionary anti-refugee politics], in contrast to Brussels' lenient policy [stigma]? [Answers:] Yes, I would fully support the Government; I would partially support the Government; I would not support the Government.

8] Would you support the Hungarian government in the introduction of more stringent regulations, according to which migrants illegally crossing the Hungarian border could be taken into custody [\{Euphemism\}, i.e. imprisoned]? [Answers:] Yes, I would fully support the Government; I would partially support the Government; I would not support the Government.

9] Do you agree with the view that migrants illegally crossing the Hungarian border should be returned to their own countries within the shortest possible time?" 39 - must be rejected, expelled back to "their own country" (which could be a war zone).

This type of argumentation is in contrast with the German campaign "Wirtschaft Zusammen Integrationsinitiativen der Deutschen Wirtschaft", which is a reaction to the refugee crisis beginning in 2015 .

\footnotetext{
38 Ibid.

39 Ibid.
} 


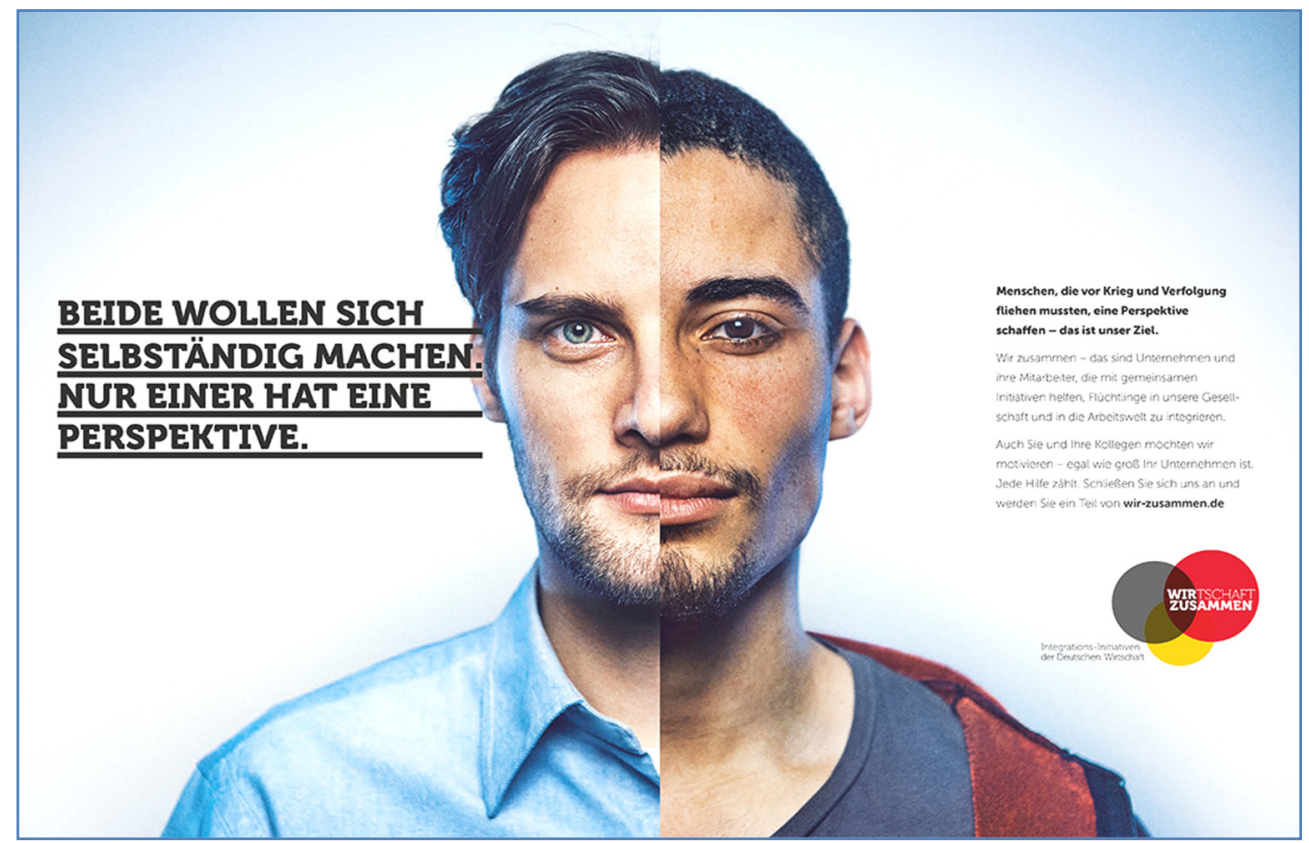

Figure 7. from the campaign "Wirtschaft Zusammen Integrationsinitiativen der Deutschen Wirtschaft. ${ }^{40}$

In connection with arguments of the type "they take away Hungarians' jobs", one should mention the report entitled Factors, directions and prospects of migration to Europe, increasing since 2015 of the Migration Workgroup of the Hungarian Academy of Sciences. The analysis answers the question whether the migration leads to the lower employment or wages of Hungarian employees as follows: "such negative effects can only be perceived in the short term, and only for some groups of Hungarian employees. In contrast, in the medium term (approx. in 4-6 years) immigration will be beneficial for Hungarian employees, because it has a positive effect on the average income level of the host countries" ${ }^{41}$ It should also be highlighted that "only $2.3 \%$ of the population living in Hungary are migrants, and the proportion of people coming from nonEuropean countries is a mere $0.3 \%$. [...] In the mirror of the numbers, the appearance of an exaggerate proportion of labour force and population of

\footnotetext{
${ }^{40}$ To see the full campaign material: http://www.wir-zusammen.de/home

${ }^{41}$ MTA Migrációs Munkacsoport: Az Európába irányuló és 2015-töl felgyorsult migráció tényezői, irányai és kilátásai (Migration Workgroup of the Hungarian Academy of Sciences: Factors, directions and prospects of migration to Europe, increasing since 2015). 46. http://mta.hu/data/cikkek/106/1060/cikk-106072/_europabairanyulo.pdf (accessed: 15.07.2017.)
} 
'foreign culture' is very distant in time" ${ }^{42}$ In addition to mentioning the positive effects of migration, the report also formulates the important insight that the need for migration is actually a constraint of Hungarian economy: "The low level of pre-2015 migration cannot be sustained in the long term, the demographic prospects, the population decrease, the sustainability of the pension fund show a forcible need for migration". ${ }^{43}$ The report also states that "by our 2015 knowledge the best "proactive" solution for alleviating the lack of labour force increasingly threatening the Hungarian economy is to accept immigrants looking at the labourforce market". ${ }^{44}$ The political recommendation of the report is that "the government create the system of institutions and support that is capable of accepting larger groups of migrants who wish to stay in Hungary". ${ }^{45}$

\section{The untimeliness figure of the refugee}

"One can subscribe to Jonathan Benthal's hypothesis of an opposition between the flows of humanitarian aid moving from the north to the south and the flows of undesirable migrants moving from the south to the north."

(Michel Agier) $^{46}$

,[...] what is happening on the world scale today is the extension and greater sophistication of various form of camps that make up a mechanism for keeping away undesirables and foreigners of all kinds - refugees, displaced, 'rejected'. In a world context dominated by the national and inter-governmental obsession with controlling mobility and frontiers, it is possible to draw up an inventory of these camps."

(Michel Agier) $^{47}$

\footnotetext{
42 Ibid. 49.

${ }^{43}$ Ibid. 53.

${ }^{44}$ Ibid. 63.

45 lbid. 68.

${ }^{46}$ Michel Agier: Humanity as an Identity and Its Political Effects (A Note on Camps and Humanitarian Government) Humanity: An International Journal of Human Rights, Humanitarianism, and Development, Volume 1, Number 1, Fall 2010, pp. 29-45.

${ }^{47}$ Michel Agier: Managing the Undesirables. Refugee Camps and Humanitarian Government. Polity Press, Cambridge, 2011, 3-4.
} 
In the context of the policies and media discourses around the refugee crisis and "migration pressure", there is an increasing level of conflict, enemy creation, exclusion, polarisation, and cover-up of problems. Although most of the refugees arriving to Europe and Hungary come from Syria, Afghanistan and Iraq, ${ }^{48}$ the events that triggered the refugee crisis are left in the background, or are not discussed at all. Covert wars and illegal attacks on these countries: in case of Afghanistan more than 220000 victims according to Physicians for Social Responsibility "Body Count" data, ${ }^{49}$ in case of Iraq "the war has, directly or indirectly, killed around 1 million people", ${ }^{50}$ in case of Syria more than 480000 victims so far. ${ }^{51} \mathrm{~A}$ drastic number of victims died in the attempt to flee from war or unstable areas, according to Migrants Files data "over 30,000 refugees and migrants died in their attempt to reach or stay in Europe since 2000 ". ${ }^{52}$

There is no mention of the neo-colonisation context of the connections of military action and humanitarian aid (or "Responsibility to Protect", "reconstruction", "stabilization," "securing human rights" or "democratization", "global war on terror") with natural resources, with the fights over oil and gas pipelines, over still existing "colonies" and markets, or geostrategically and energetically important territories, which has left behind an immense destruction, chaos and radicalisation. There is also no mention of the fact that the refugees from so-called "failed states" are vulnerable not only because of armed conflict, oppressive regimes, and terrorist organisations, but also because of climate change, extreme poverty, economic crises, and increasing social inequality. Another fact that is always overshadowed as well is that "gemäß den Untersuchungen des Stockholmer Institutes für Friedensforschung (SIPRI) die fünf ständigen Mitglieder der UNO-Sicherheitsrats, eigentlich zuständig für den Weltfrieden, zugleich die fünf größten Waffenexporteure sind. [...] Neben den fünf Vetomächten im UNO-Sicherheitsrat gehören die NATO-Länder Deutschland, Spanien, Italien und die Niederlande gemäß SIPRI zu den zehn größten Waffenexporteuren der Welt". ${ }^{53}$ One more aspect that is left in the background is that the threatening reality-construction increasingly gives way to an Orwellian vision of control. In the shadow of the language and rhetoric of terrorism, generating fear is fundamental. In addition to the terrorist threat, the private sphere is gradually liquidated, and it seems we could give almost anything to preserve the illusion of security. It is again a time of wire-tapping, data storage,

\footnotetext{
48 Ibid. 27.

${ }^{49}$ Body Count: http://www.psr.org/assets/pdfs/body-count.pdf 15.

50 Ibid.

${ }^{51}$ http://www.iamsyria.org/death-tolls.html

52 http://www.themigrantsfiles.com/

53 Daniele Ganser: Illegale Kriege. Wie die NATO-Länder die UNO sabotieren. Eine Chronik von Kuba bis Syrien. Orell Füssli Verlag, Zürich 2016.
} 
the giving up of the private sphere, and the limitations of civil liberties. Extremist parties, anti-immigrant, anti-refugee groups, anti-"Islamic" and "Islamophobic" groups gain more and more ground. Society looks thus increasingly polarised, binary, schizoid and frustrated, and the bravely idyllic vision of a heterogeneous, hybrid, multicultural Europe and West is less and less present. Multicultural cohabitation seems to be pushed to the background, giving way to a psychophantomatic state, which leaves almost everybody a loser, while millions of people are destroyed and debilitated by armed conflict, the privatisation and financing of war, by the fights over geostrategically and energetically important territories, in the contemporary geopolitical context.

Hannah Arendt, Edward Said, Giorgio Agamben, Homi K. Bhabha and Seyla Benhabib formulate deeply insightful analyses and descriptions about the condition of being a refugee, covering the time from the second decade of $20^{\text {th }}$ century, when the international law started to codify the relationship between refugees and host societies. J. Derrida in his democracy-critic also emphasises that "through the expulsion or deportation of so many exiles, stateless persons, and immigrants from a so-called national territory already herald a new experience of frontiers and identity - whether national or civil", ${ }^{54}$ and a new form of slavery is rising. Slavoj Žižek also describes that "with the new epoch of the global capitalism, a new era of slavery is also rising. Although it is no longer a direct legal status of enslaved persons, slavery acquires a multitude of new forms: millions of immigrant workers [...] who are de facto deprived of elementary civil rights and freedoms; the total control over millions of workers in Asian sweatshops often directly organized as concentration camps", 55 and many refugees are in a similar situation. Michel Foucault speaking about the Vietnamese refugees, "boat people", showed that they are placed in a "Heterotopian" space, "somewhere else", in "other places", where multiple exclusions take place. "The ship is the heterotopia par excellence", 56 and the "refugees are the first to be confined outside" ${ }^{57}$ Agamben formulates that according to bare life a new class of society is outlined, which is excluded from the sphere of political existence. Similarly to

\footnotetext{
54 Jacques Derrida: Specters of Marx. The State of the Debt, the Work of Mourning and the New International. Routledge, New York and London, 1994. 101.

${ }^{55}$ Slavoj Zizek: We Can't Address the EU Refugee Crisis Without Confronting Global Capitalism. In. http://inthesetimes.com/article/18385/slavoj-zizek-european-refugee-crisis-and-global-capitalism 56 "Heterotopias;" radio broadcasts on France Culture, December 7-21, 1966.

57 lbid.
} 
Foucault and Agamben, Michel Agier created the concept of "hors-lieux", "offplaces", and the phenomenon of the ghetto as "place of banishment" ("ban-lieu"), as a kind of extraterritoriality in Zygmunt Baum's terminology. ${ }^{58}$ In the term of Engin Isin and Kim Rygiel "a group of 'abject spaces' on borders, in zones, and in camps can be observed, where they are 'neither subjects nor objects, but abject'."59

Despite the common features like De-humanization and De-justification, the new (in)human classless or out-class society of the refugees includes complex and differentiated groups, and represents a large spectrum of persons, beyond the stateless and persecuted persons, the war refugees, poverty refugees, economic refugees, climate refugees, internally displaced persons; another category is the group of people in emergency (living in war zone, starving from hunger etc.). For these groups, it is extremely difficult or inaccessible to obtain the refugee status, creating either "the world of 'illegal and clandestine aliens' and 'nonsuit immigrants' (or 'closed files;' in the UNHCR term for those who no longer have the right to anything)" 60 or the word of the camps, be it self-installed or official. The "more fortunate", who live in official refugee camps, become the inhabitants of an ambiguous system of institutions which becomes totalitarian, as a humanitarian totalitarianism of a sort, where the bureaucratic and totalitarian organisations like the UNHCR, following a globalised economic and political agenda, supplement a certain western political strategy.

All these ideas outline a new class, or better said, a classlessness or outclass part of the global society, where the rights are radically injured or people are totally de-justified. Based on this, a de-humanisation takes place, whereby the lives of millions of human beings become worthless, just a rational calculation, a technical management, or is nullified. This condition takes place in the frame of a "state of exception" - as Agamben claims - which seems to be permanent, "which has become the rule", an "endless emergency" in terms of Agier. All this development shows the contemporary new (in)human condition: (i) the sacrificable life (the many millions of people dying in illegal wars, by chemical weapons etc. ), (ii) the life unnecessary for politics: the residents of the camps (which are managed by the totalizing bureaucratic biopolitics), (iii) the ambiguous space and institution of the global network of camps, (iv) the loss of the fundamental rights for a broad

\footnotetext{
58 Michel Agier: From refuge the ghetto is born. Contemporary figures of heterotopias. Polity Press, Cambridge, 2011. 265-292.

59 Isin, Engin, and Kim Rygiel. Of Other Global Cities: Frontiers, Zones, Camps. In Drieskens, Barbara; Mermier, Franck and Wimmen, Heiko (eds.): Cities of the South: Citizenship and Exclusion in the 21st Century. London, Saqi, 2007. pp. 170-209.

${ }^{60}$ Michel Agier: Ibid. 287.
} 
section of society, (v) the automatic de-justification of further generations (generations born in camp), (vi) the refugee as a consumer, as a new market and sector (because of the need of the infrastructure and goods necessary for surviving in refugee camps), (vii) anonymous test subjects for new technologies, (viii) the mass of potential victims of human trafficking, prostitution, sexual exploitation, forced labour, transplant commercialism, etc.

It can be concluded that, as long as the following things do not change: 1 . a profit-oriented humanitarian aid, 2 . humanitarian indifference, 3 . marketcolonising capitalist economic strategy, 4. financing of war or dictatorial and autocratic, extremist regimes and groups, 5. an attitude indifferent to durable peace and stability, 6. a (geo)political context that closes eyes to any kind of violations of human rights, and 7. a strategy that counterweighs increasing social imbalance then the refugee crisis or "migration pressure" of today is merely an initial stage of the refugee crisis, migration and humanitarian catastrophe started by the disintegrating Middle-East and African countries or "third world countries". However, the currently ongoing phenomena, instead of any constructive development, and instead of the systematic or non-systematic liquidation of the factors that produced and fostered the problem, only show a general social mistrust and the radicalisation of extremism.

Moreover, the current situation seems to suggest that the EU is either forced to engage itself, by its rules and fundamental principles, to "solve" the refugee crisis (in which case the "solution" is in fact improvised and illusory), or it must give up or radically reformulate its fundamental values and rights, questioning or at least challenging its constructed vision and legitimacy. 